IOSR Journal of Pharmacy

e-ISSN: 2250-3013, p-ISSN: 2319-4219, www.iosrphr.org

Volume 2 Issue 6 || || Nov-Dec. 2012 ||| PP.60-66

\title{
Histopathological changes due to some chlorinated hydrocarbon pesticides in the tissues to cyprinus carpio
}

\author{
${ }^{1}$ Shanta Satyanarayan*, J. P. Kotangale Ahana Satyanarayan ${ }^{2}$ \\ Sanyogita Verma ${ }^{3}$ \\ ${ }^{1,2,3}$ National Environmental Engineering Research Institute (NEERI), \\ Nehru Marg, Nagpur 440020
}

\begin{abstract}
Chronic bioassay studies were carried out using the chlorinated hydrocarbon pesticides like DOT, BHC, Aldrin and Dieldrin using fresh water fish Cyprinus carpio as test organism. The aim of the studies were $: i)$ the effect of these chlorinated hydrocarbons on fish on prolonged exposure to the sublethal concentration levels determined from acute toxicity studies; ii) their effect on vital internal organs (Histopathological studies) such as gill, kidney, liver and intestine, before and after the exposure, to ascertain internal injury, if any.

The accumulation of the chlorinated hydrocarbons in different tissues clearly indicate the potential hazards of the pesticides. In small doses, these may not be detrimental from water pollution point of view, but can create great hazard by accumulating in fish tissues.

Different tissues showed different accumulation of pesticides. Histopathological changes were observed in vital organs. Gills showed swelling and thickening in their filaments. In some cases, the epithelial wall of the secondary lamellae was completely destroyed and the pillar cells showed complete fusion. Mucous cells were completely destroyed. In most cases, the epithelium of the secondary lamellae was separated from the supporting pillar cells. Complete necrosis and sloughing of secondary lamellae from the supporting pillar cells was observed.

Liver showed abnormal fatty degeneration. Enlargement of liver was observed in few cases. Necrosis, congestion and fatty degeneration were also observed.

Kidney tissue also showed abnormalities. Large vacuolated cells were seen in the glomerulii. Acute tubular necrosis was seen. The glomerulii were shrunken with sloughed necrotic glomerulii lining cells in the lumen. Intestine showed fusion of intestinal folds and acute epithelial necrosis.
\end{abstract}

Keywords-Chlorinated pesticides, chronic assay, Histology, Cyprinus carpio, Tissues, Mucous cells, Lamella.

\section{INTRODUCTION}

Pesticides have been found to be highly toxic not only to fish but also to the organisms, which constitute the food chain ${ }^{[1,2,3]}$. Pesticides in general, are used very extensively in agriculture, forestry, public health and in veterinery practices. Hence, it is necessary to study the immediate and chronic effects of pesticides on fish, which form a part of human diet. These compounds have a tendency to accumulate in small quantities in lower fish food organisms and ultimately biomagnify themselves in the fish species. Therefore, it would be very pertinent to study the effect of such chlorinated hydrocarbons on long-term exposure by chronic studies to ascertain the residual toxicity.

It is reported that the chronic toxicity may ultimately cause death or may result in the elimination of species or individuals over a long period of time, through a host of effects such as induced sterility, interference with an organism's natural defence mechanism, loss of appetite, blindness, hyper exitability or other weaknesses ${ }^{[4]}$ and reduction in fertility ${ }^{[5]}$. Chronic studies were shown to be useful in determining long term effects on fishes $^{[6,7]}$.

Review on available literature on fish and environmental pollutants indicate that the sublethal doses of most of the pesticides cause varying extent of histopathological injuries to different organs in fishes; the amount of damages are usually dependent on dose, duration of exposure and type of pgsticide ${ }^{[8-14]}$. Literature reviews are available on pollution and fish physiology and also discussed harmful impacts of different heavy metals, pesticides, dyes etc. on various life activities of fishes. It is reported that most of the pollutants induce mortality, genotoxicity and histopathology thus impairing respiration, metabolism and enzyme activities in affected fishes. 
In this context it was thought worthwhile to study the chronic effects of some selected pesticides on the vital organs of a freshwater fish Cyprinus carpio.

\section{MATERIALS AND METHODS}

A constant dosing device designed and fabricated in the institute was used in this study ${ }^{[9]}$ and is shown in Figure 1. Other experimental details are given in the earlier paper by the author ${ }^{[17]}$. The test fish, Cyprinus carpio were procured from the Department of Fisheries, Maharashtra State, Nagpur, India. The pesticides Aldrin, Dieldrin, BHC and DOT were procured from M/s Fluka Company, Switzerland. The concentration of Aldrin, Dieldrin, BHC and DDT used for the experiment were $0.005,0.002,1.000$ and $0.002 \mathrm{mg} \mathrm{L}^{-1}$ respectively. The test fish were kept in the test solution of known concentration for a period extending over to 20 and 30 days. After every 24 hours fresh test solution was introduced. The experiments were run in replicates for all pesticides. Fishes were taken out at an interval of 20 and 30 days, sacrificed and various tissues viz. liver, kidney, gills and intestine were dissected out, fixed in Bouin's fluid, preserved and processed for histological study. Only the photographs indicating well pronounced histopathotogical changes have been included in this paper.

\section{OBSERVATIONS AND DISCUSSION}

During 30 days exposure, liver of Cyprinus carpio showed highest accumulation of pesticides, in comparison to other tissues. Kidney showed most accumulation next only to liver. It was observed that longer the exposure time, the higher was the accumulation. Next to liver and kidney, intestine showed higher accumulation of aldrin, BHC and dieldrin ${ }^{[18]}$.

Histopathological studies were carried out on various fish tissues. Control tissues of gill, intestine, kidney and liver are shown in Plate 1. Detail of histopathological changes observed are discussed below.

\section{GILLS}

The gills in control fish showed a row of long thin filaments, the primary lamellae, projecting from the gill arch like the teeth of a comb. On its distal and ventral surface were the secondary lamellae. Secondary lamellae consist of an envelop of epithelial cells, usually one layer thick, supported and separated by pillar cells arranged in rows (Plate 1).

The treated gills of fish showed the damage to varying extent depending on the exposure period. As the exposure time increased the degree of damage also increased. Dieldrin and DDT treated gills exhibited more destruction of the gill filaments. DDT treated gills showed a partial detachment of epithelium after 20 days exposure time. Secondary lamellae were thickened and completely disorganised and disintegration just set in. In case of 30 days exposed gills, the cell mass between secondary lamellae were thickened to such an extent that interlamellar spaces were completely occluded giving the filament a compact appearance (Plate $2 \mathbf{2 a} \boldsymbol{\&} \mathbf{2 b}$ ). Complete disintegration of secondary lamellae was observed in gills exposed to dieldrin for 30 days (Plate 2d) and in 20 days the disintegration was to a lesser extent.

Aldrin treated gills showed severe damage both in 20 and 30 days period; with shrinkage of secondary lamellae with a slight curling bend in 20 days exposure (Plate 2c). In 30 days exposure, gill showed curling of the tips of secondary lamellae. Epithelial wall was destroyed completely and only pillar cells were left.

Gills exposed to BHC showed complete destruction of epithelial walls. Secondary lamellae showed shrinkage. On exposure to 30 days the gill lamellae were completely disintegrated with pillar cells showing the debris of mucous cells and blood cells (Plate 2e).

Reports on haemorrhage in primary gill lamellae and shortening of secondary gill lamellae after the exposure to sublethal level of endosulfan is available ${ }^{[19]}$. Secondary gill filaments at many places were degenerated after 15 days exposure to phosphomidon ${ }^{[20]}$ as was observed in the present studies with chlorinated pesticides.

Studies on the toxicity of aldrin to Cyprinus carpio has been reported ${ }^{[14]}$. At same sublethal concentration as in the present study, the destruction of epithelium accompanied by loss of mucous cells on top of gill lamina was observed.

\section{LIVER}

The study on naphthalene showed formation of lesions and hyperplasty occlusions in gills of Trachinotus carolinus $^{[21]}$. Also, epithelial lifting, hyperplasia and hypertrophy of respiratory epithelium, lamellar fusion and aneurysms in the gills have been reported in Neotropical fish ${ }^{[22]}$.

Liver of control fish composed of large number of polyhedral hepatic cells containing a granular cytoplasm. Nuclei of the liver cells are vesicular with a large nucleolus, numerous bile ductules, blood capillaries and sinusoides. The sinusoides were filled with erythrocytes. Sinusoides were irregularly distributed between polygonal hepatocytes and lined by endothermal cells with very prominent nuclei (Plate 1). 
Liver and spleen tumors and lipidosis in liver were associated with acute exposure of organochlorine pesticides PAH and heavy metals in the eel Anguilla Anguilla ${ }^{[23]}$. Main alterations observed in liver on exposure to crude oil include hepatocyte swelling and cytoplasmic vacuolization, megalocytosis, coagulative dispersed necrosis, lymphocytic infiltration, melanomacrophate aggregates, spongiosis perichotangitis and bile stagnosis when exposed to crude oil ${ }^{[24]}$.

The most consistently damaged organ is liver. In most of the cases generalised swelling and pyknosis of hepatocytic nuclei often with cytoplasmic vacuolation were seen. Clumping of blood cells were observed in dieldrin and DOT exposed fish livers. Aldrin exposed fishes showed enlargement of nuclei of the blood cells with localised acute necrosis in 30 days exposure. In general, DOT, dieldrin and BHC treated fish liver showed more pronounced damage than aldrin treated ones, both in case of 20 days and 30 days exposures (Plate 3e).

Studies on toxicity of aldrin to Cyprinus carpio liver has indicated vacuolation in the hepatic cells ${ }^{[25]}$. At same concentration as in present study, the hepatic cells vacuolated with slight change in the position of nucleus, slight atrophy of cells in peripheral and central zone. Hypertrophy of hepatic cells, necrosis and vacuolation in cytoplasm have been reported due to the effect of pesticide ${ }^{[26]}$. The connective tissue was degenerated and some cells showed the rupture of cell membrane.

Degeneration of hepatocytes with extensive pycnosis and involution to carbofuran exposed Channa punctatus. This trend was similar to the present observalions ${ }^{[27]}$. Massive necrosis of liver cells with swollen or disintegrating cells replaced by debris after selenium exposure has been reported in literature ${ }^{[28]}$. Vacuolation, loss of regular polygonal shape and marked degeneration in hepatic cells were observed in the present studies, have also been reported in literature ${ }^{[29]}$.

\section{KIDNEY}

The general histological structure of kidney of control fish showed a large number of uriniferous tubules composed of cuboidal epithelial cells having a central or marginal nucleus and eosinophilic cytoplasm. The renal corpuscle comprised of a glomerulus surrounded by a single layered Bowman's capsule. Many blood capillaries and vessels containing blood cells were seen in the kidney. The intertubular space was full of haemopoietic tissue, consisting of erythrocytes, lymphocytes and immature blood cells (Plate 1).

Acute cytological necrosis of haemopoietic tissue was observed in case of 30 days dieldrin treated kidney. Vacuolation and complete disintegration of cuboidal cells of epithelial layer of glomerulii was observed with BHC. Kidney of 30 days DOT treated fish showed haemopoietic necrosis and vacuolation (Plate 3c). The glomerulii were shrunken when exposed to dieldrin. Generally aldrin, dieldrin, DOT and BHC treated kidney after 20 days exposure showed acute necrosis (Plate 3d). Poor supply of oxygenated blood due to pesticide toxicity may be the cause of necrosis.

Observation on the inflammation of Bowman's capsule and induced degenerative changes in renal tubules in carbofuran exposed kidney is reported ${ }^{[26]}$. Further it is reported that severe vacuolization of tubular epithelium followed by pyknosis resulted. Wider lumen and rupture in uriniferous tubules is also reported ${ }^{[19]}$. Ruptures and flattening of renal epithelial cells along with displacement of nuclei, widening of tubules lumen, necrosis in haemopoietic tissue and shrinkage of glomerulus in Channa striatus after the exposure to pesticides is reported ${ }^{[30]}$. Reports indicate shrinkage in both glomerulii and epithelial cells, coalescence of adjacent renal tubules in Anabas testudineus after sublethal exposure to furadan ${ }^{[31]}$.

\section{INTESTINE}

A general histological structure of intestine of control fish showed a simple mucoid columnar epithelium overlying a submucosa, often richly endowed with eosinophilic granule cells and limited by a dense mucoularis mucosa and fibroelastic layer (Plate 1).

Changes observed in the intestine due to toxicity were the flattening of intestinal folds, fusion with each other, shrinkage of cells and acute epithelial necrosis. Studies revealed more destruction in tissues of the 30 days exposed fish than the 20 days. DOT exposed intestine showed more flattening of intestinal folds followed by dieldrin and aldrin. Fish exposed to dieldrin and other insecticides die owing to induced histopathological changes in liver and intestine ${ }^{[27]}$. BHC and lindane have also been reported to induce histopathological changes in liver of fish. The present study also indicated similar trend.

Flattening of the intestinal folds were well defined in case of aldrin exposed fish for 20 days period (Plate 3a). In 30 days exposed tissue the intestinal folds were completely flattened thereby reducing the surface area, necrosis was also very defined. Same trend was observed in case of dieldrin also (Plate 3b). In case of DOT, acute necrosis was observed. Flattening of intestinal folds was seen in 20 days exposed tissue whereas in 30 days exposed tissue fusion and necrosis of epithelial ceils were very acute. In case of BHC, vacuolation and acute necrosis were observed. 
Reports on degenerative changes and rupture in tip of villi, loss of structural integrity of mucosal folds and degeneration \& necrosis of submucosa in the intestine of Channa punctatus after the exposure to carbofuran are found in literature ${ }^{[23]}$. Report on vacuolization in submucosa \& circular muscles and dilation of columnar \& goblet cells of mucosal folds were observed in the present studies[26]. Destruction of columnar epithelium, submucosa fused with muscles and serosa was found in broken condition after 10 days exposure to malathion $^{[28]}$. These histopathological changes were observed in the intestine of Cyprinus carpio subjected to chlorinated pesticide in the present studies.

All the different groups of pesticides or even the different pesticides of the same group do not have the same effect on fishes. Moreover, the mode and site of action of different pesticides differ ${ }^{[29]}$.

\section{REFERENCES}

[1]. Apostol S. (1979) The toxicity of certain pesticides to protozoa. Proc. Symp. Environ. Biol.: 97 -102.

[2]. Ghosh T. K. \& Konar S. K. (1979) Effects of sublethal levels of the insecticide aldrin on fish and fish-food organisms. Proc. Symp. Environ. Biol.: 103-112.

[3]. Muley D. Y. \& Mane U. H, (1986) Toxicity of endosulfan 35 EC to estuarine edible clam Katelysia opima (Gmelin) from west coast of India. Proc. Natl. Symp. Environ. Biol.: 117-123.

[4]. Holden A. V. (1964) The possible effects on fish of chemicals used in agriculture. J. Proc. Inst. Sew. Purif. $4: 361$ $-368$.

[5]. Dutta H.M. \& H.J.M. Meijer (2003) Sublethal effects of diazinon on the structure of the testis of bluegill, Lepomis macrochirus: a microscopic analysis. Environmental Pollution 125(3):355-360.

[6]. Grant B. F. \& Mehrle P. M. (1973) Endrin toxicosis in rainbow trout (Salmo gairdneri). J. Fish. Res. Bd. Can. 30 (1): $31-40$.

[7]. Silbergeld E. K. (1973) Dieldrin effects of chronic sublethal exposure on adaptation to thermal stress in freshwater fish. Environ. Sci. \& Technol. 7 (9): 846 - 849.

[8]. Kulshrestha S.K.\& Arora N.(1984) Fish and pesticides-histopathological parameters. Intl. J. Acad. Ichthyol.5:1 - 9.

[9]. Advait Bhagade (2012) Impact of bioaccumulation of few PCBs and PAHs in freshwater fish Rasbora daniconius and Puntius ticto. Thesis submitted for Ph.D. in Zoology to RTM Nagpur University, Nagpur.

[10]. Thais de Cruz Alves dos Santos, Phan Van Ngan, Maria Jose de Arrunda Campos Rocha Passos \& Vincente Gomes (2006) Effects of naphthalene on metabolic rate and ammonia excretion of juvenile Florida pompano Trachionotus carolinus. J. of Experimental Marine Biology and Ecology. 335 (1) : 82 - 90.

[11]. Oliviera Ribeiro C. A., Vollaire Y., Sanchez-Chardi A. \& Roche H. (2005) Bioaccumulation and the effect of organochlorine pesticides, PAH and heavy metals in the eel (Anguilla anguilla) at the Camargue Nature Reserve, France. Aquatic Toxicology. 74 (1): $53-69$.

[12]. Esam Agamy (2012) Histopathological liver alterations in juvenile rabbit fish (Siganus canaliculatus) exposed to light Arabian crude oil, dispersed oil and dispersant. Ecotoxicology \& Environmental Safety. 15 : 171 - 179.

[13]. Marina M. P. Camargo \& Claudia B.R. Martinez (2007) Histopathology of gills, kidney and liver of Neotropical fish caged in an urban stream. Neotropical Ichthyology 5(3): 327 - 336.

[14]. Mario Pacheco \& Maria Ana Santos (2002) Biotransformation, genotoxic and histopathological effects of environmental contaminants in European eel (Anguilla anguilla L.). Ecotoxicology \& Environmental Safety 53(3) : 331 - 347.

[15]. Pedro M. Costa, Mario S. Diniz, Sandar Caeiro, Jorge Lobo, Marta Martins, Ana M. Fereira, Miguel Caetano, Carlos Vale, T. Angel Delvalls \& M. Helena Costa (2009) Histological biomarkers in liver and gills of juvenile Solea senegalensis exposed to contaminated estuarine sediments: A weighted indices approach. Aquatic Toxicology 92: 202-212.

[16]. N. Korkmaz, E.I. Cengiz, E. Unlu, E. Lysal, M. Yanar (2009) Cypermethrin induced histopathological and biochemical change in Nile tilapia (Oreochromis niloticus), and the protective and recuperative effect of ascorbic acid. Environmental Toxicology \& Pharmacology 28(2): 198-205.

[17]. Houjuan Xing, Shu Li, Zhilei Wong, Xuejiao Gao, Shiwen Xu, Xialong Wang (2012) Oxidative stress response and histopathological changes due to atrazine and chlorpyrifos exposure in common carp. Pesticide Biochemistry \& Physiology 103(1): 74-80.

[18]. Jui-Pin Wu, Hon-Cheng, Da-Ji Huang (2008) Histopathological and biochemical evidence of hepatopancreatic toxicity caused by cadmium and zinc in the white shrimp Litopenaeus vannamei. Chemosphere 73(7): 1019-1026.

[19]. Pandey A.C.,Krishan Gopal \& Pandey A. K.(2000) Pollution and fish physiology:A Review. Aquacuft. 1 (1): 1 - 8.

[20]. Srinivasan M. V. \& Dabadghao S. B. (1970) Laboratory model constant dosing device. Environ. Health 12 (2): 178- 180.

[21]. Satyanarayan S. \& Ramakant (2004) Bioaccumulation kinetics and bioconcentration factor of chlorinated pesticides in tissues of Puntius ticto (Ham.). J. Environ, Sci. \& Health (Part B). B39 (2): 321 - 332.

[22]. Shanta Satyanarayan, P. L. Muthal, K. P. Krishnamoorthy and S. N . Kaul (1999). Bioaccumulation of organic chlorine pesticides in different fish tissues, intern. J. Environ. Studies Vol. 56. pp. 201-213.

[23]. Muley D. V., Kamble G. B. \& Gaikwad P. T. (1996) Endosulfan toxicity in the freshwater fish Tilapia mossambica. Proc. Acad. Environ. Biol. 5 (1):49 55.

[24]. Jayantha Rao K., Ramamurthi K. \& Murthy V. S. R, (1984) Sublethal chronic effects of phosphomidon on functionally active tissue, the gill of a freshwater edible fish Tilapia mossambica. Intl. J. Acad. Ichthyol. 5:23 - 26.

[25]. Ratnakar A. V. \& Awasthy C. (1979) Toxicity of aldrin to Cyprinus carpio. Proc. Syrnp. Environ. Biol.: 377 - 382. 
[26]. Sastry K. V. \& Sharma S. K. (1979) Toxic effects of endrin on liver and kidney of a freshwater fish. Proc. Symp. Environ. Biol.: 337 - 342.

[27]. Krishna Gopal \& Ram M. D. (1994) Carbofuran induced histopathological changes in certain tissues of freshwater fish Channa punctatus (Bioch). Proc. Acad. Environ. Biol. 3 (1): 43 - 47.

[28]. Srivastava A. K. \& Srivastava A. K. (1995) Histopathological changes in the liver associated with selenium exposure in the freshwater Indian catfish Heteropneustes fossilis. J. Adv. Zool. 16 (1): 30 - 33.

[29]. Mathur D. S. (1965) Histological changes in the liver of certain fishes induced by dieldrin. Science \& Culture 31 ; $258-259$.

[30]. Kulshrestha S. K., Shrivastava R. S. \& Arora N. (1984) Toxicity of two pesticides on the kidney of a freshwater teleost Channa striatus (Bloch). Proc. Sem. Effects of Pesticides on Aquatic Fauna : 63 - 70.

[31]. Bakthavathsalam R,, Ramalingam R. \& Ramaswamy A. (1984) Histopathology of liver, kidney and intestine of the fish Anabas testudineus exposed to furadan. Environ. \& Ecology 2 (4) : 243 - 247.

[32]. Mathur D. J. (1962) Histopathological changes in liver of certain fishes as induced by BHC and lindane. Proc. Nat. Acad. Sci. India Section B. 32 (4): 429-434.

[33]. Kasotiya S. (2004) Effects of malathion on the intestine of Channa gachua (Ham.). Ind. J. Environ, \& Ecoplan. 8 (3): 723 - 726.

[34]. Pandey B. N., Chanchal A. K., Singh S. B., Prasad S. \& Singh M. P. (1979) Effect of some biocides on the blood and oxygen consumption of Channa punctatus (Bloch). Proc. Symp. Environ. Biol.: 343 - 348.

Figure 1: Schematic Diagram of the Experimental Set-up for Chronic Bioassay Studies

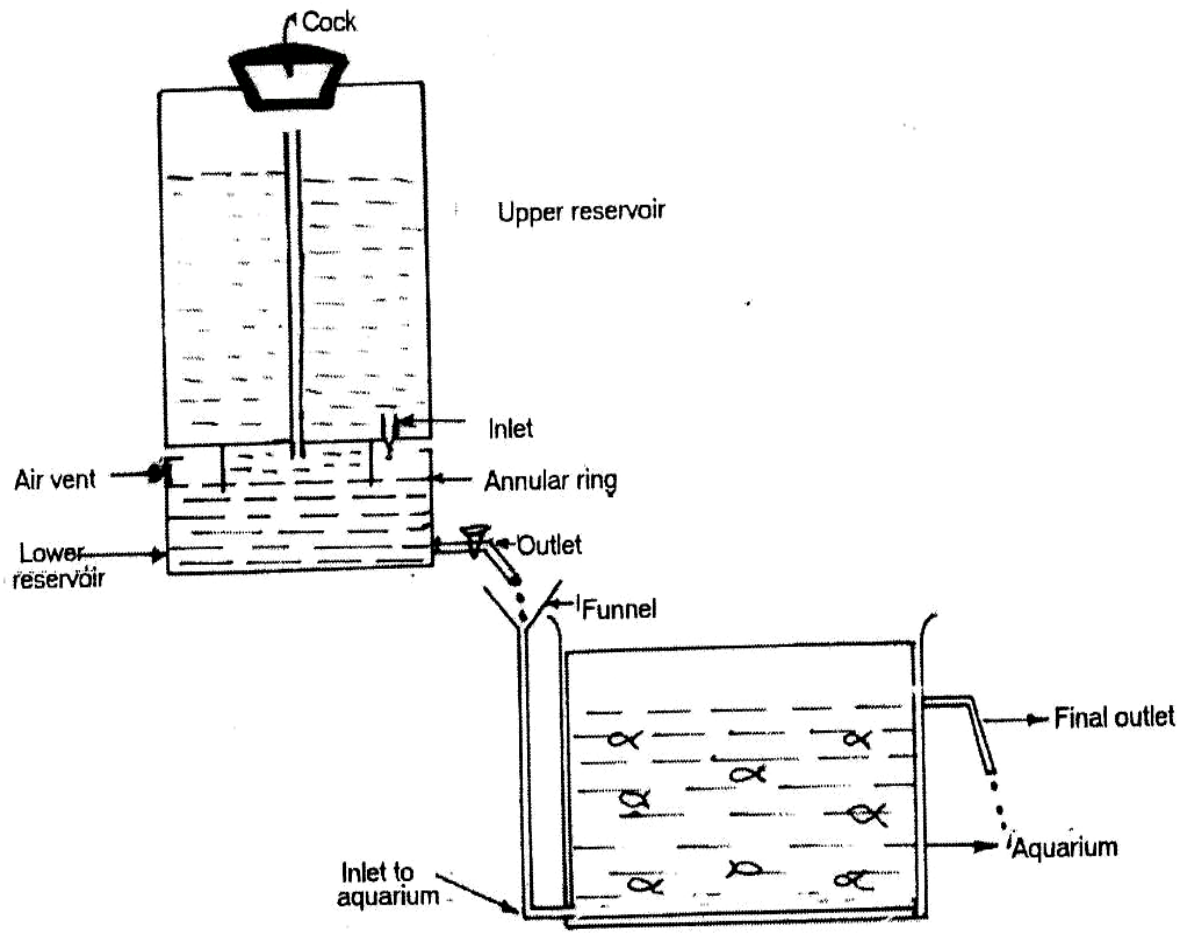



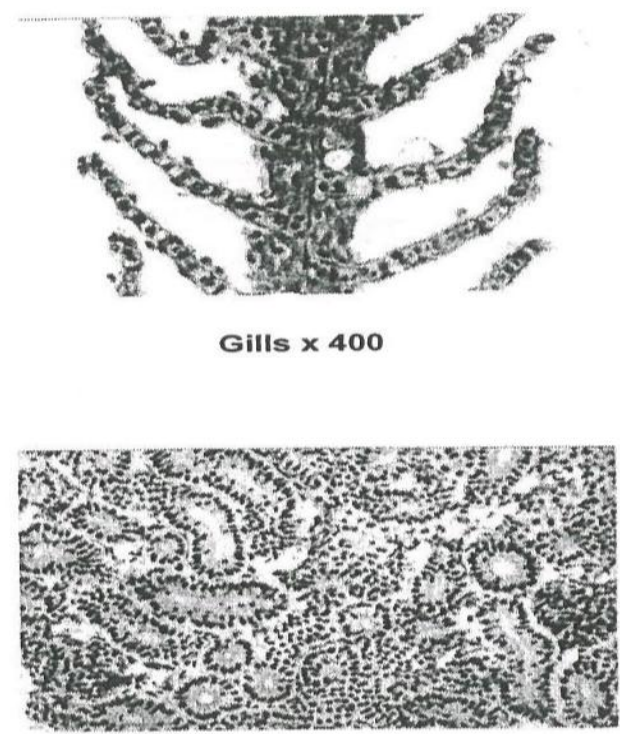

Kidney x 250

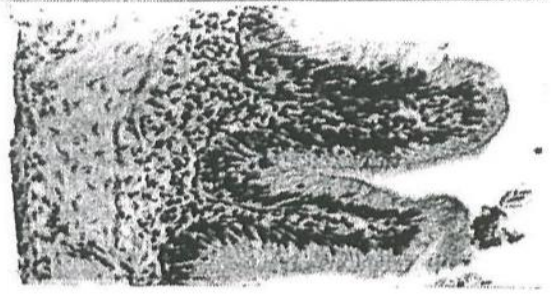

Intestine $\times 250$

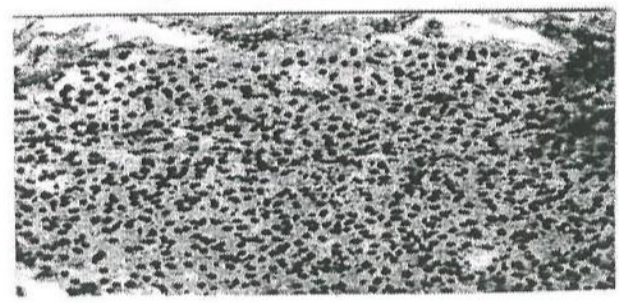

$$
\begin{gathered}
\text { Liver } \times 320 \times \\
(5 c a n \text { Fig } 4: 52)
\end{gathered}
$$

Plate 1: Histological Structure of control Tissues of Cyprinus carpio

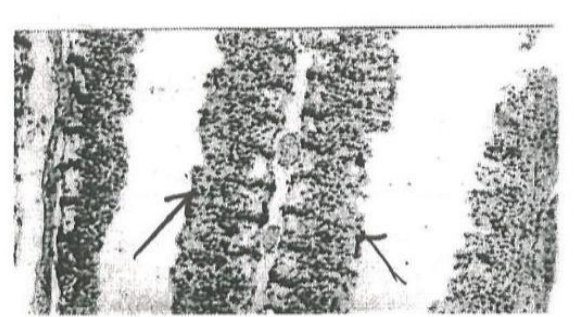

(a)

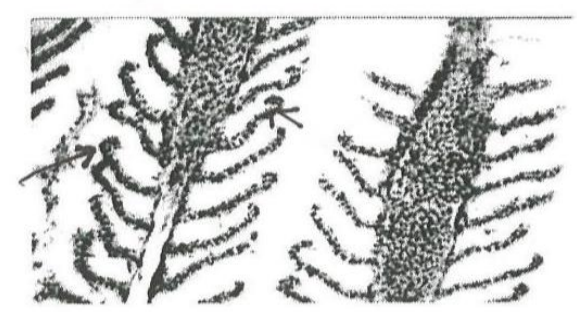

(c)

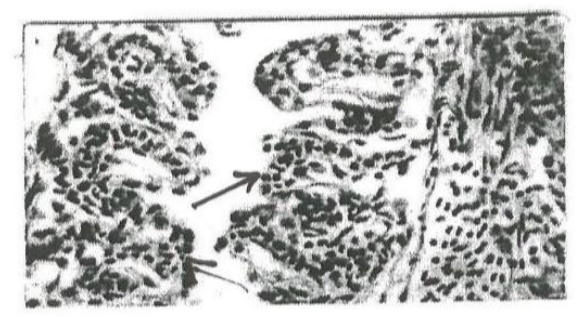

(b)

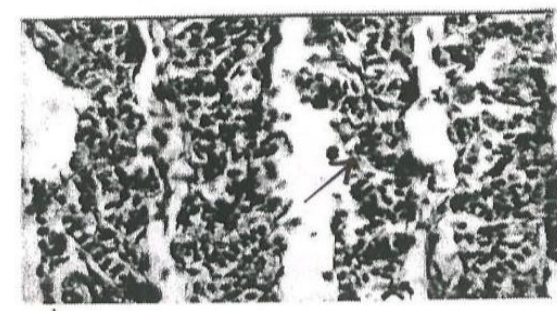

(d)

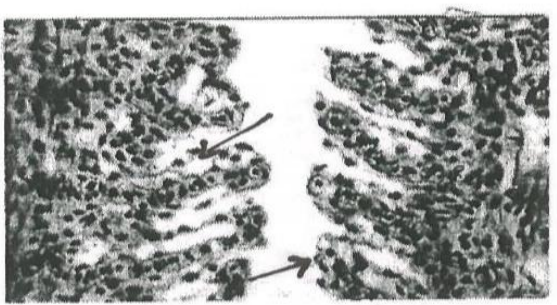

(e)

a) Gills (30 days, DDT) $x 160$

Plate 2: Histopathological Changes observed

b) Gills (30 days, DDT) $x 400$

c) Gills (20 days, Aldrin) x 160

d) Gills (30 days, Dieldrin) $x 400$

e) Gills (30 days, BHC) $x 400$ 


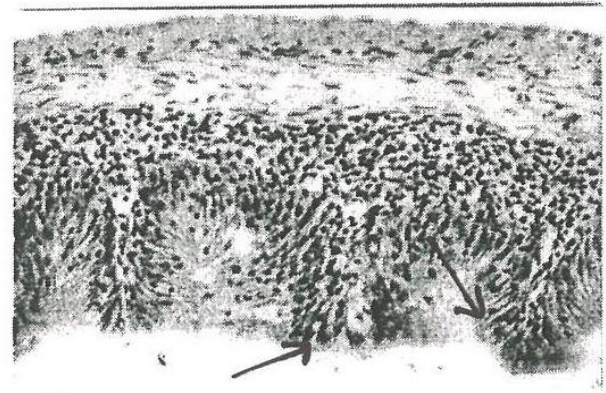

(a)

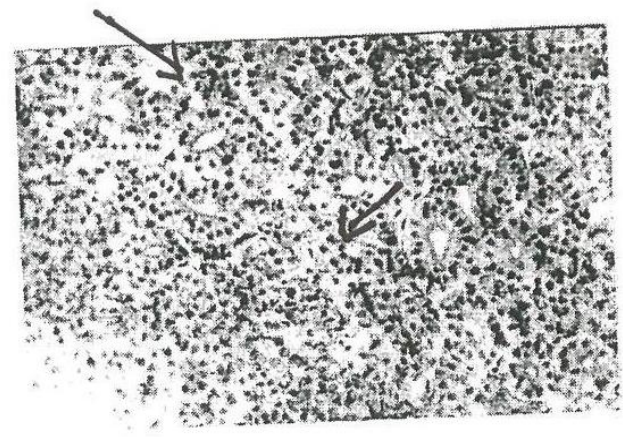

(c)

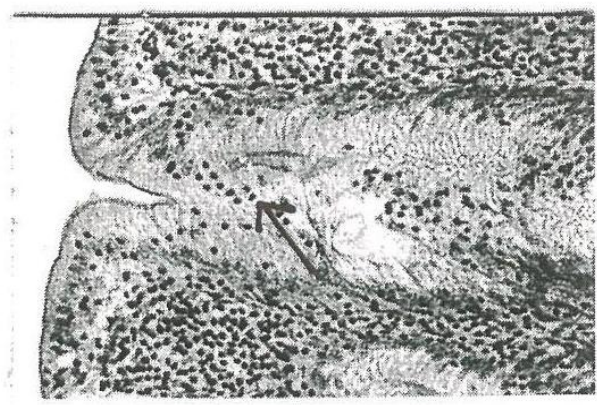

(b)

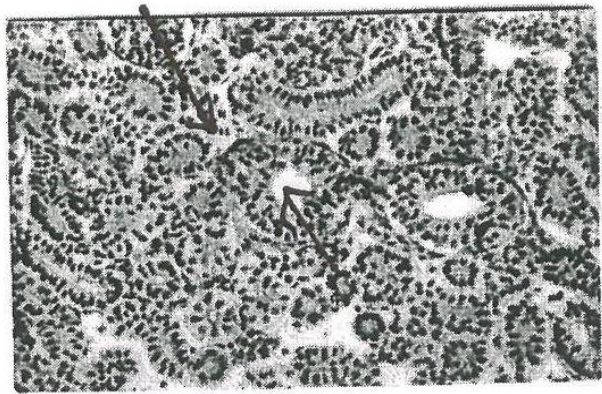

(d)

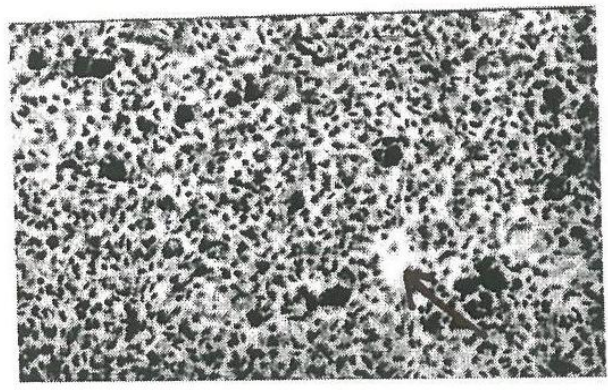

(e)

Plate 3: Histopathological Changes observed

a) Intestine (20 days, Aldrin) x 250

b) Intestine (30 days, Dieldrin) x 250

c) Kidney (30 days, DDT) x 250

d) Kidney (20 days, BHC) x 250

e) Liver (30 days, DDT) x 320 